\title{
Analysis of Reading Culture Implementation in Jambi University's Elementary School Partners
}

\author{
Yantoro Yantoro ${ }^{1}$ \\ ${ }^{1}$ Faculty of Teacher Training and Education, Jambi University \\ Corresponding author. Email: yantoro@unja.ac.id
}

\begin{abstract}
Students' reading ability is the main skill that students must have to achieve their success in the learning process. School as the main instrument in improving the quality of human resources must be able to develop this reading ability by implementing a reading culture or habit in schools. The purpose of this study was to determine how the elementary school implements the reading culture or habit in schools. The research location is in six elementary school partners of the Jambi university. The research subjects were school principals and teachers. Data were collected through observation, interviews, and documentation. Data were analyzed through data reduction, data display and data verification. The results showed that the implementation of the reading culture in the partner elementary schools of the University of Jambi was generally carried out by mapping students' reading abilities and skills, habituation activities, modeling, building cooperation, fulfilling facilities and infrastructure. The implementation of the reading culture of each school differs depending on the principal's leadership, the active role and concern of the teacher in implementing the reading culture and community participation (guardian of students) in supporting the implementation of a reading culture in schools. Therefore, schools have an important role in implementing a reading culture in various ways to improve the reading abilities and skills of students.
\end{abstract}

Keywords: Implementation, reading culture, partner elementary schools, enthusiasm

\section{INTRODUCTION}

School programs in relation to reading skill is one of the key indicators to measure the quality of the schools. This statement provides a very clear picture for education providers, especially school principals and teachers, of the importance of developing reading habits or instilling a reading culture in schools. Reading habits must be instilled as early as possible in students starting from the beginning of entering school, meaning that starting from grade one student must be taught and trained and developed literacy skills and abilities to read. Reading is a skill, as a skill, reading ability must be developed by practicing through various stages of strong tips, strategies and techniques in building the will to read [1].

Reading ability is very much needed and occupies an important and strategic position in absorbing current knowledge and information because advances in science and information are presented in the form of reading which requires a person or student to read it in as much detail as possible.

There is a positive correlation between reading skills and abilities of students and the success of following the learning process. This can be proven by the learning achievements they have achieved. Students who are able to read well and quickly will achieve very satisfying learning outcomes compared to students who have reading abilities and skills rather slowly. Seeing the importance of abilities and skills in reading that students must have, the school, in this case the principal, as the principal person in charge of the quality of education, must have superior and appropriate strategies or tips capable of fostering and developing a reading culture for school members.

The students' ability and skills in reading are a hot topic of conversation in Indonesia at the moment, even the Minister of Education and Culture Nadiam Makarim spoke up and was concerned about the low literacy skills of Indonesian children in reading. This is evident from the PISA score report (Program for International Student Assessment) for Indonesia in 
2018 announced by the OECD (The organization for Economic Co-operation and development) which places Indonesia number 72 out of 76 countries with a total score of 376.This condition is a problem which is serious for the image and quality of education in Indonesia which needs to be addressed as soon as possible. The minister of education emphasized that "all leaders from the ministry to the level of school principals and teachers must immediately move to find solutions or breakthroughs to improve reading abilities and skills to develop the reading culture of Indonesian children."

Elementary schools are the first formal educational institutions that have the obligation to equip participants. Students in securing reading ability and skills. For this reason, elementary schools must have the right strategy or method in implementing a reading culture in schools. Principals and teachers must be energized on how to implement a reading culture in schools so that students are imbued with enthusiasm for reading which in turn can improve reading skills and abilities. The principal must have a vision and enthusiasm and a high work ethic as a school leader in an effort to implement a reading culture in schools, and teachers must also have concern and creativity in applying a reading culture to students.[2]

Jambi University builds networks with various elementary schools to become partner schools in collaboration with Tanoto Foundation in an effort to improve the quality of education at the basic education level. Various programs and collaborations have been carried out through mentoring activities in elementary schools, one of which is how the school's strategy is in implementing or implementing a reading culture in schools. This can be seen from the interest in reading in each partner primary school that has shown good results and brought changes in a positive direction, even though there are still some obstacles faced.

Based on this background, it is interesting to do research on the analysis of the implementation of reading culture in partner schools at Jambi University.

\section{REVIEW OF THEORY}

\subsection{Culture Reading}

Culture is a thought, reason or something that has developed and taken root in society, something that has become a habit in society that is difficult to change.[3] Meanwhile, reading (reading) is an activity to see and understand the content and meaning of what is written. From these two meanings, it can be defined that reading culture is essentially a habit that is contained in a person or group of people in which there is a logical and complex thought process, including the skills to capture and understand the content of the reading and be able to interpret and reflect.

The development of science and information technology is currently very fast, promising some information that is needed by students. The development of science and information technology is documented in the form of reading which is also transformed directly through reading forms, including articles, newspapers and books. To be able to understand and access these readings, the ability to read plays a very important role. Reading skills that are manifested in the understanding of reading content mastered by students have a positive influence and have a big impact on the success of following the learning process in school even in real life in the community. Students who have the ability and skills to read quickly and with quality will achieve proud learning achievements in every subject.

Hogdog in Tarigan [4] explains the opinion:

"reading is a process that is carried out and used by readers from the writer's ideas and opinions through the media of words / written language. This process demands that a group of words that constitute a whole will be involved in a glimpse and the meaning of the individual words will be identified.

According to Ermanto [1] reading skills are receptive which includes the skills to absorb information or knowledge. Reading skills include (1) mechanical reading or preliminary reading (2) comprehensive reading or reading comprehension.

The development of the world and human life today This is very fast and complex placing information as an element that plays a very important role, for that schools must be able to equip students about mastering information as early as possible by instilling a reading habit or getting used to reading through several media, both books and electronic media. Schools must be able to equip students in finding, selecting, processing and utilizing information obtained for positive and useful life needs

Research conducted in the United States provides a strong lesson on the importance of reading skills, and building a reading culture, especially in the early grades when children just started school. In this study concluded that children who are slow reading in the early grades will experience more severe failure in subsequent grades. This is known as the 'Matthew effect'. In economics, the Mattew effect means "Whoever is diligent and rich is getting richer, but the lazy is getting poorer". implementation in education, meaning that those who are diligent in studying and reading will become rich and those who are slow to read and learn will become poorer. [5]

\subsection{Principal Leadership}

A new paradigm in school education management, better known as School Based Management (MBS) provides broad autonomy to schools for how to improve the quality of education. All education providers in schools especially school principals are required to have smart and quality ideas in an effort to realize the educational goals mandated in Law No. 20 of 2003 concerning the National Education System, namely to make human beings who are skilled, have noble character, have noble character, have extensive knowledge and love the homeland and people. 
As a formal educational institution, schools have complex and unique characteristics. It is said that the complex contains the meaning of a school as an educational organization in which there are various dimensions that are interconnected and influence and mutually determine, are unique because schools have unique characteristics that are not shared by other organizations [6]. Seeing the complexity and uniqueness of these, it is very necessary for a leader or principal who is able to understand, understand and have the right strategy in implementing this diversity and uniqueness.

The principal as a determinant of the color of education in schools is one of the elements in the education provider that is most responsible for the success of the quality of education. "The close relationship between the quality of the principal and school life" is an appropriate statement, this can be proven that school failure is largely determined by the quality of the principal's leadership.

The principal must have a strong leadership vision manifested in his work ethic. Leadership is a plural interaction and mutual influence between leaders and those who are led in achieving predetermined goals in real terms and together As a leader, the principal is required to be able to mobilize all the potential that exists within and outside the school as the concept of school based management. Principals are required to understand the vision and mission as well as education management strategies as a whole that are oriented towards quality. The new paradigm in education gives broad powers to schools to develop all the potential that is owned both within and around the school. The ability of the principal as a leader can be seen from the personality, knowledge of the vision, mission and goals of the school, the ability to make decisions and the ability to innovate accordingly. with the needs of the school. Meanwhile, the principal's personality is reflected in the honesty they have, strong selfconfidence, responsibility, ability and courage to take risks, have a big and stable spirit and are able to be role models of those they lead. [2]

Indicators of quality education units can be measured. of the quality of the learning process carried out by the teacher in the classroom. The quality learning process is characterized by the total participation of students in the learning process and the teacher only acts as a facilitator. The participation of students in the learning process is determined by their reading ability and skills. Based on the description above, it can be concluded that the ability and reading skills of students are a determining element of the quality of education in schools.

\section{METHODOLOGY 3.1. Approach}

In an effort to get a real picture in accordance with the actual conditions and are natural, the approach used in this research is a qualitative descriptive approach. "A qualitative descriptive approach, can provide a real picture according to the actual situation and is natural to see the social reality phenomenon that exists in society in accordance with what is happening to the research object and tries to draw that social reality to the surface as a marker, character, characteristics, models, signs about a certain condition or picture they have [7]

\subsection{Location and Research Subjects}

This research was conducted at partner elementary schools of Jambi University which consisted of 6 elementary schools

\subsection{Data Collection Techniques.}

There are several data collection techniques, namely observation or observation techniques, interview techniques, and documentation study.

\subsubsection{Observation is a way of collecting data that can be obtained by making direct observations in the field, recording is done systematically and validly and can be justified.}

Table 1. Instruments Guidelines for Observation / Observation

\begin{tabular}{|l|l|l|}
\hline No & \multicolumn{1}{|c|}{ Focus Observation } & Results Observation \\
\hline 1 & Aspects of Principal Leadership & \\
\hline 2 & Strategy for implementing reading culture & \\
\hline 3 & Results of implementing reading culture & \\
\hline 4 & $\begin{array}{l}\text { Physical evidence or authentic evidence of the implementation } \\
\text { of reading culture }\end{array}$ & \\
\hline
\end{tabular}

\subsubsection{Interview}

To get direct data from research subjects interview techniques using interview guidelines. The interview guidelines are as follows: 
Table. 2. Aspects of Information Disclosure and Research Subjects

\begin{tabular}{|l|l|}
\hline \multicolumn{1}{|c|}{ Empirical Information } & \multicolumn{1}{|c|}{$\begin{array}{c}\text { Subjects of } \\
\text { Interview }\end{array}$} \\
\hline $\begin{array}{l}\text { Aspects of Principal } \\
\text { Leadership }\end{array}$ & Principals of School \\
\hline $\begin{array}{l}\text { Strategies for } \\
\text { implementing a reading } \\
\text { culture }\end{array}$ & Principals, Teachers, \\
\hline $\begin{array}{l}\text { Results of implementing } \\
\text { a reading culture }\end{array}$ & $\begin{array}{l}\text { PrincipalPrincipal } \\
\text { Teachers }\end{array}$ \\
\hline $\begin{array}{l}\text { Evidence of authentic } \\
\text { evidence of } \\
\text { implementing a reading } \\
\text { culture }\end{array}$ & Teachers. \\
\hline
\end{tabular}

\subsubsection{Documentation Study}

Collecting data other than observation and interview data, the authors conducted a documentation study. Documentation data, used for triangulation materials to determine the suitability of the data.

\subsection{The Data Collection Process}

Stages of the data collection process were carried out through various stages. The stages include the orientation and overview stage, the exploration stage (focused exploration), and finally the stage member check.

\subsection{Data Analysis}

In analyzing data to be more focused and get valid results and scientifically accountable, this data analysis is guided by what has been done by [8], namely by carrying out activities through various stages starting from reviewing all the data There are various sources, data from interviews, observations and documentation that have been recorded in the field activity notes

\section{RESEARCH RESULTS AND DISCUSSION}

\subsection{Research Results}

The data collected through observation, interviews and documentation can be described as follows:

The principal, through his leadership, takes various ways to combat the low reading interest of students by developing a reading culture. This method starts from in-depth analysis of the condition of the school with all kinds of available resources by looking at the strengths, strengths and weaknesses and obstacles. Based on the results of the analysis, the school's strategy to develop a reading culture through 1) Making mapping through data collection of students starting from the early grades (low class) to the high class on reading abilities and skills 2) providing facilities and infrastructure related to the implementation of the reading culture 3) carrying out various kinds routine activities to foster a reading culture 4) Providing concrete examples from school principals and teachers in fostering students' reading interest and culture and establishing reading clinics.

\subsubsection{Making a class map about reading ability}

Based on the observations and documentation of the principal and the early grade teacher (low class) doing reading test activities for early grade students. The collected data will become a database to determine the activity plans that will be provided by students. Based on the results of the initial test, it showed that the students' ability and skills in recognizing letters and reading simple words were good enough. Almost $85 \%$ of students could read simple words, but if the number of syllables was large, they would experience difficulty. For grade two reading abilities and skills are quite good, being able to read, but the ability to understand the reading content is still weak, while grades 3 and 4 the abilities and skills and understanding of reading content are quite good, while grades 5 and 6 have the ability and skills and understand the reading content. already well.

From the research results, the reading that is liked by low-grade students is reading that is pictured and in color, while the high-class reading books that are liked are not all like pictures but more about the contents of the book. In learning to read activities that are interspersed with seeing funny pictures in books and telling stories.

\subsubsection{Procurement of facilities and infrastructure that support the development of a reading culture.}

Based on the results of the research, the principal's leadership tips in developing a reading culture are by completing the facilities and infrastructure that support the implementation of a reading culture. The facilities that have been equipped are a reading corner in the classroom along with supporting books, a reading cart equipped with reading books, a reading garden and a reading gazebo. The reading facilities are well arranged so as to make reading comfortable. From the research results Data obtained, the principal provides reading books, both fiction and non-fiction. Especially for lowgrade children, the books provided are books with interesting pictures and colors, so that students feel happy and interested in reading them. Provision of facilities and infrastructure carried out by the school in 
collaboration with parents, school committees and the community.

\subsubsection{Doing various kinds of routine activities or habituation}

Based on observations and interviews with the principal, there are activities that are routinely carried out by schools to foster a reading culture, including:

a) Before the lesson begins, students and teachers carry out silent reading activities for 15 minutes, the results of observations of almost all classes before Class hours begin at the first hour of silent reading activities.

b) Carry out reading activities together every Friday followed by all school members in the school yard.

c) Carrying out Iqro activities "and there is a daily deposit of short letters to the homeroom teacher.

d) There are storytelling and storytelling competitions that are held routinely every semester

e) Asking students to make a resume of the subject matter that will be studied the next day

f) Doing reading activities in the school garden or gazebo relaxed, relaxed but excited

\subsubsection{Providing concrete examples (exemplary)}

Exemplary is a necessary attitude or what can be an example, in this case is the example of the principal and teacher in developing a reading culture.

The action of the principal in an effort to foster and build a reading culture in schools is by cultivating an exemplary attitude or being a role model. Principals and teachers must be able to be role models or examples to their students

Based on the results of observations and interviews, the exemplary forms of school principals and teachers that they do in building a reading culture include:

1) Doing reading activities in between spare time, especially during break

2) time. read together with students in the school garden

3) The principal and teachers are actively involved in summarizing books or making reviews.

4) Provide motivation to students who get from the experience of reading books.

\subsubsection{Building Collaboration, The tactics}

Principal's in developing a reading culture are carried out by building collaboration with guardians, school committees, communities and government and private agencies.

Based on the results of observations, interviews and documentation of school heads in various forms of cooperation with the guardians of students. This collaboration is carried out almost every time on an ongoing basis by encouraging the parents to always pay attention and motivate their children to study at home.
They held regular meetings to discuss the learning achievements of their sons and daughters. A form of collaboration is also carried out by asking for donations of reading books to complete books at school.

Collaboration with student guardians and school committees in the provision of reading gardens, reading corners and other reading facilities, where the guardians of students play an active role in making donations. The ability of the principal in building communication with the guardians of students is also extraordinary. The school principal always communicates school activities through the school group WA, thereby fostering trust in the school by guardians. Collaboration is also carried out with the private sector, namely a bookstore in the Singkut subdistrict, where students are given the opportunity to read. Collaboration with regional libraries was built, namely the visit of a library car to school. All of that aims to build a reading culture in schools.

\subsubsection{Reading Clinic}

Based on observations, the principal and teacher's tips for developing a reading culture in schools are to establish a reading clinic.

Reading clinics are services provided to students who experience reading delays which affect their reading abilities and skills, as well as to students who want to explore reading abilities and skills. This reading clinic is carried out by special teachers on Saturdays by guiding students, assisting in reading, guiding and understanding the meaning of words. This activity has a very good impact on developing a reading culture in schools.

\subsection{Discussion}

Reading is the most important part of human life, because through reading, people gain knowledge and information that is very useful in their lives. Reading a lot will influence the mindset and perspective of humans in acting and behaving. Knowing how important reading is, the reading culture movement must be instilled early in school. Schools must carry out careful data collection starting from the early grades (when entering school) to the high class to find out students' ability in reading through tests of ability and speed and accuracy in reading. This is important as a basis for taking action given to students.

Good and friends [9] conducted a study by measuring the ability to read words per minute of children from grade 1 to grade 5 . The conclusion is as follows: The chart below is the reading per minute. The $\mathrm{Y}$-axis shows the ability to read letters per minute, while the $\mathrm{x}$-axis shows the grade level, namely grade 1 to grade 5 . The red color represents $10 \%$ of children with the lowest reading ability, while the green color represents $10 \%$ of children with moderate reading ability. If it is seen that the longer (the higher the class) 
the greater the difference in reading ability in the two groups.

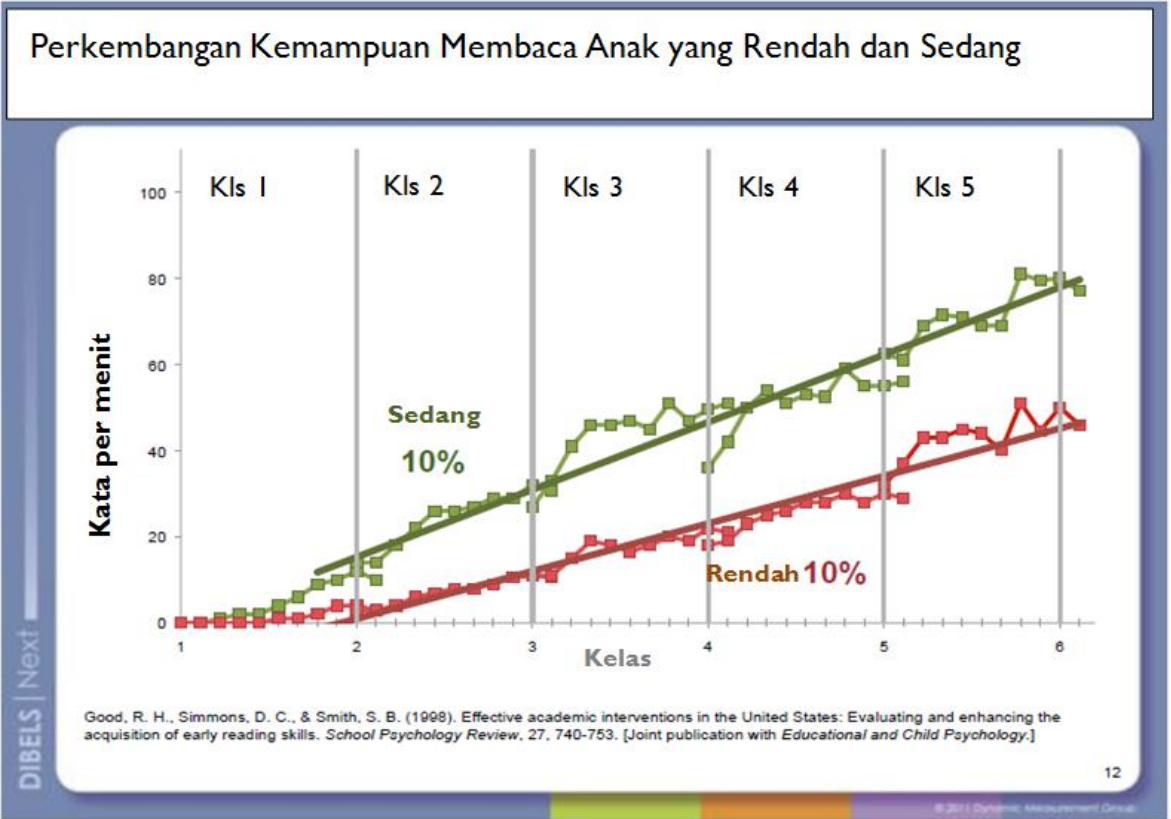

Figure 1 Source: Good III, RH, Simmons, DC, \& Smith, SB [9]. Effective academic interventions in the United States: Evaluating and enhancing the acquisition of early reading skills.School Psychology Review

Seeing the importance of reading in students, schools must be able to assist in fostering and developing interest in reading through the creation of a reading culture. In this case, school principals and teachers play an important role in creating and developing a reading culture. The leadership of the principal must be directed to create a conducive climate in an effort to build a reading culture. The principal must have good strategies and strategies in an effort to foster and develop a reading culture for their students. The love of reading must be cultivated as early as possible in students starting from the early grades.

Based on the results of breakthrough research conducted by the principal at SD Muhammadiyah One Singkut, in developing a reading culture, through various activities. The activities carried out were mapping by doing tests for all students starting in reading skills. The test results are used as the basis for carrying out the types of action given. In the early grades the principal made activities to provide assistance regularly and individually to students. Principals and teachers are aware and understand correctly that reading is a complex skill, complex and involves many skills, therefore individual mentoring is needed. The teacher must introduce characters and punctuation marks, connect the characters and their punctuation marks with formal linguistic elements, and connect the two with meaning.[10]

The habit of cultivating and developing a reading culture is carried out by the school by doing the habit of reading quietly before class starts for 15 minutes together. This is in accordance with the mandate of
Permendikbud No. 23 of 2015 [11] concerning reading habit, which mandates that before starting the subject matter, silent reading activities are carried out. This activity is very appropriate in fostering student reading interest. Someone who has an interest in reading, they will be motivated to pay attention to the reading activity. One of the characteristics of school principal leadership is being able to provide examples or real examples for followers [6] Exemplary by principals and teachers in fostering a reading culture is done by always doing reading activities on the sidelines and routine activities at school. Exemplary nature needs to be developed in school, because by giving real examples it will encourage students to do this in reading activities.

The collaboration program with various parties carried out by the principal to build a reading culture can provide positive encouragement in creating student interest in reading. Through cooperation, the school will be assisted in the procurement of facilities and infrastructure. Students also get the opportunity to study outside of school. Principals are required to have competence in developing schools in various ways, including by collaborating with various parties. The principal must have managerial leadership abilities in accordance with Permendikans [12] No. 13 of 2007 concerning the competency standards of school principals.

The reading skills and abilities of students are very diverse, some are diligent and read fast, but students also find it difficult to do fast learning activities. Seeing this condition, the principal's strategy of making reading clinics is very helpful in developing reading 
interest. Reading clinics are directed not only to help students with reading difficulties but also to strengthen, add and deepen reading skills and abilities.

\section{CONCLUSION}

The principal as the highest leader in the education unit determines the color and face of the school. The leadership quality of the principal is the central force that determines the quality of the school. The success of the quality of education in schools is determined by the quality of learning. Quality learning is determined by the ability of students to absorb knowledge through reading abilities and skills.

The leadership of the principal in developing a reading culture is carried out with various tips, namely making a class map of reading skills, providing facilities and infrastructure, doing habituation, being an example of building cooperation with student guardians and establishing a reading clinic. Although the principal through his leadership is able to grow and build reading culture in schools.

\section{REFERENCES}

[1] K. Ermanto. (2019). Intelligent reading skills. Raja raja grafindo persada
[2] Mulyasa. Becoming the Principal of a Professional School. Bandung: Remaja Rosda Karya. 2005

[3] Big Indonesian DictionarY. 2002. Ministry of National Education: Jakarta. Pustakahall

[4] H G Tarigan. Membaca sebagai suatu keterampila berbahasa,Bandung angkasa. 2005

[5] Tanoto Foundaton. Modul 1 Praktik baik dalam manajemen berbasis sekolah. Jakarta ,Tanoto foundation. 2005

[6] Wahyosumijono. (2007). Kepemimpinan Kepala Sekolah tinjauan teoritik dan permasalahannya Jakarta: PT Raja Grafindo Persada

[7] B Bungin. (2007). Qualitative research Co. Inc: jakarta Prenadagroup media

[8] Sugiono. Metodologi Penelitian Kualitatif kuantitatif dan R\&D. Bandung : Alfabeta. 2005

[9] R. H. Good III, D. C. Simmons, \& S. B. Smith, (1998). Effective academic interventions in the United States: Evaluating and enhancing the acquisition of early reading skills.School Psychology Review.

[10] G. Broughton, (1997) Teaching English as a foregin language, London: Routledge.Paul

[11] Permendikbud No 23 Tahun (2015). Tentang Penumbuhan Budi Pekerti., Jakarta : BNSP

[12] Peraturan Menteri Pendidikan Nasional No 13 Tahun 2007 Tentang Standar Kepala sekolah 